\title{
THE ROLE OF INDUSTRY 4.0 IN ACHIEVING SUSTAINABLE DEVELOPMENT GOALS
}

\author{
Mohammed Ali Berawi ${ }^{1 *}$ \\ ${ }^{1}$ Faculty of Engineering, Universitas Indonesia, Kampus UI Depok, Depok 16424, Indonesia
}

This note is presented as part of the continuous discussion on how science and technology contribute to improving quality of life and sustaining our planet.

Sustainable development goals (SDGs) are established to end poverty, improve health and education, and promote prosperity and well-being through environmental sustainability. The 2030 Agenda philosophy of "no one left behind" requires global partnerships and participation in the integration of environmental, social, economic, and governance dimensions in the process of development. The concept of sustainable development is conceived as a balance of sustainable economic growth and ecological regeneration. Sustainable development requires the implementation of appropriate environmentally friendly technologies that are both efficient and adaptable to local conditions. In this situation, eco-technology can facilitate the conservation and restoration of the environment through the integration of engineering and ecological principles.

The development of science and technology plays a significant role in achieving SDG targets by improving the efficiency and effectiveness of new and more sustainable development methods. Investments in green technology, efficient and effective processes, safer materials, and improved performance and outcomes are some of the results of such development. These actions show how technological applications and developments have been utilized to comply with the principles of social, economic, and ecologic welfare.

Developing technology, creating innovation, and producing breakthrough solutions are critical for delivering SDG targets, from eradication of poverty to improving food security to reversing climate change. Investments are a vital instrument to foster appropriate technological development. Strong collaboration in private and public partnerships will accelerate appropriate and sustainable technological development, scale-up, and transfer in order to generate more social benefits and economic returns while reducing environmental impacts.

The development of frugal and high-tech innovation requires the application of better solutions that produce effective products, processes, and services to meet new requirements and needs. Achieving sustainable economic growth will require changes in business processes. Industries need to become energy and resource efficient and minimize waste. Technological developments for utilizing renewable energy resources, building urban water systems and sustainable public infrastructure, increasing food production, and producing environmentally friendly materials and products are among the pathways by which technology will significantly contribute to the achievement of SDG targets.

Through Industry 4.0, technology today plays a significant role in sustainable social, environmental, and economic development. Consideration of the scarcity and constraints of natural resources in new technological development will lead to more robust and better technological processes that produce more attractive products and services. 
Information and communication technology is driving innovation, efficiency, and effectiveness across all sectors and resources by providing everyone with the potential to access and share information and then utilize it to create new opportunities. It is changing the way businesses are managed. ICT can also be used to assist governments in delivering better public services as well as creating smart and resilient cities. ICT has improved the way we work and live as well as our outlook on the development of urban areas. The fourth industrial revolution has made it possible for us to transform production, management, and governance into more effective and efficient systems in connected societies.

The well-being of our future is dependent on our production of technology to govern our climate, health, social equity, and stability. Industry 4.0 can be used to mitigate problems and provide solutions for enhancing our way of life through sustainable products and services. The creativity and innovation of technological development contributes to improving the global environment by producing green, resource-secure, and inclusive economies for all. Furthermore, technologies such as the Internet of Things, artificial intelligence, data analytics, machine learning, 3D printing, etc. can be used to create, expand, and monitor the effectiveness of sustainable development and environmental compliance across the globe. Industry 4.0 can be efficiently used to control and improve resources, energy, water, and waste by connecting and automatically exchanging information via intra- and inter-systems. As technology changes the way we live, it will continue to have a profound impact on the way we regenerate and protect our environment through sustainability.

Challenges to future civilization-including population pressure, climate change, energy security, environmental degradation, water and food availability, and sustainable development - need to be wisely addressed. We are all given the opportunity to collaborate and work together to reduce inequality, end poverty, protect the environment, and improve our society's quality of life and well-being. Sustainable development requires institutional and value changes as well as cultural adjustments. Sustainable development must be incorporated into mainstream policies to promote national and international cooperation.

\section{Fostering Science and Technology Development}

The improvement of technologies that produce alternative methods, techniques, and end products is required to accelerate developments in all research areas. In this context, this edition presents twenty papers dedicated to systematic and empirical research in science and engineering that foster the development of science and technology.

The first paper, written by J. Ameh, A. Soyingbe, and O. Oyediran, examines acceptability and use of innovative bamboo products for construction of residential buildings in Nigeria. The authors argue that the optimization of bamboo for construction will boost economic activity, reduce capital flight for importation of machinery and constituents for conventional building materials, and enhance the country's gross domestic product.

The next paper, written by I. Laili, A.R. Abdul-Aziz, S. Suresh, S. Renukappa, and A. Enshassi, presents a project management competency framework for industrialized building system construction. The framework emphasizes appropriate information during the initial phase, operational issues in the planning phase, interfacing in the implementation phase, time management in the monitoring phase, and quality assurance in the closing phase.

The third paper, written by M. Hanid, M.S.M. Danuri, M. Othman, O. Mohamed, K.M. Ye, and M.A. Berawi, examines critical success factors (CSFs) for university-industry collaboration (UIC) projects. The authors argue that universities must focus more on the quality of the researchers, commitment, and financial support, whilst industries should emphasize constant communication and strong teamwork to ensure the success of the collaboration. 
The fourth paper, written by Yanuar, Ibadurrahman, and S.A.A. Putri, investigates the resistance characteristics of submerged projectiles with bow variations based on the hull envelope equation. The authors discuss the optimum design suitable for projectile-shaped objects in submerged conditions, such as submarines and torpedoes.

The fifth paper, written by K. Agrebi, A. Belhadj, and M. Bouhafs, examines a threedimensional numerical simulation of a gas tungsten arc welding process. The authors demonstrate the space-time temperature evolutions at each point of the welding process from the beginning of welding until the return to thermal balance.

The next paper, written by K. Suastika, Sahlan, W.H. Nugroho, A. Zubaydi, M.N. Misbah, and Murdjito, investigates the fatigue life of waste steel reused as keel structures for tsunami buoys. The authors argue that the observed reduction in fatigue strength is ascribed to the shaft's previous use, and the calculated fatigue life is approximately 9.5 years with a safety factor of 5 .

The seventh paper, written by T.M. Fagbola, S. Thakur, and O. Olugbara, presents news article classification using the Kolmogorov complexity distance measure and artificial neural networks. The authors argue that the prototype indicates high reliability for deployed applications and the ability to synergize decision making on a specific problem domain of interest, such as fault-tolerant systems.

The eighth paper, written by D.S. Sisodia and U. Verma, proposes the distinct multiple learnerbased ensemble smotebagging method for classification of binary class imbalance ratio problems. The authors argue that the ML-ESB algorithm performed significantly better on four datasets with comparatively large numbers of features and high-class IR, and it performed moderately on two datasets with small numbers of features and low-class IR.

The next paper, written by D.M. Uliyan and M. Alhusainy, presents a secret-key image steganography technique using random chain codes. The authors argue that the proposed technique successfully achieved the three goals of strong steganography techniques, namely, capacity, robustness, and undetectability.

The tenth paper, written by N. Sandra, K. Kawaai, I. Ujike, I. Nakai, and W. Nsama, examines the effects of bleeding on the corrosion of horizontal steel bars in reinforced concrete column specimens. The authors argue that the replacement of fly ash is effective in facilitating more uniform quality in the column specimens due to a lower level of bleeding water and higher resistance to segregation and pozzolanic reactions.

The eleventh paper, written by C.V.S.R. Prasad and T.V.S.V. Lakshmi, examines the effect of crushed sand and bacillus subtilis on the cantabro loss of bacterial concrete. The authors argue that the optimum bacterial solution dosage to improve concrete strength at any age is $10 \%$ by weight of cement.

The next paper, written by G.A. Kristanto and W. Koven, examines antibiotic-resistant Escherichia coli in a hospital wastewater treatment plant (WWTP). The authors argue that the average antibiotic resistance of $E$. coli is $4.17 \%$; however, the WWTP process increased the resistance to $20 \%$.

The thirteenth paper, written by F.I. Anuar, T. Hadibarata, Muryanto. A. Yunarto, D. Priyandoko, and A.A. Sari, determines the effect of chemical modification of the stinky bean peel (SBP) to enhance its ability to adsorb dye. The authors argue that raw SBP has the potential to be used as a biosorbent to remove PR from aqueous solutions, with a biosorption time of 12 hours and removal of $77.43 \%$.

The fourteenth paper, written by M. Hayat, E. Saepudin, Y. Einaga, and T.A. Ivandini, presents a CdS nanoparticle-based biosensor development method for aflatoxin determination. The 
authors argue that a linear concentration range of $0-70 \mathrm{ppb}$ aflatoxin, with a sensitivity of 20 $\mu \mathrm{A} / \mathrm{mM}$ and a detection limit of $30 \mathrm{ppb}$, was achieved by this method.

The next paper, written by Helmiyati and Y. Anggraini, examines the use of nanocompositebased rice husk cellulose for biodiesel production. The authors argue that the biopolymer-based nanocomposite utilizing nanocellulose from rice husks with inorganic $\mathrm{Fe}_{3} \mathrm{O}_{4}$ nanoparticles has good potential for use as a green biocatalyst.

The sixteenth paper, written by M. Khalil, G. Rahmaningsih, J. Gunlazuardi, and A. Umar, examines the influence of the surface plasmon resonance (SPR) phenomenon of plasmonic gold $\mathrm{Au}$ ) nanoparticles on the optical bandgap of anatase titanium dioxide $\left(\mathrm{TiO}_{2}\right)$ nanoparticles. The authors argue that the integration of $\mathrm{Au}$ nanoparticles alters both the light absorption behavior and optical bandgap of $\mathrm{TiO}_{2}$ as well as the presence of the SPR phenomenon to widen the light absorption range of $\mathrm{TiO}_{2}$ to the visible spectrum.

The next paper, written by I. Sujandari, R.A. Wayasti, Zulkarnain, E. Laoh, and A.M.M. Rus, Prawiradinata. I, examines the public opinion on ride-hailing service providers using aspectbased sentiment analysis. The authors argue that strategies and policies for customer satisfaction and loyalty can be maintained and improved using this method.

The eighteenth paper, written by F.D. Wicaksono, Y.B. Arshad, and H. Sihombing, presents a techno-economic analysis of an oil and gas production sharing contract, which is subjected to uncertainty from fluctuation in natural gas prices and production reservoir capacity. The authors argue that quantified risks and uncertainties come from two parameters, reservoir production and the natural gas price.

The nineteenth paper, written by Y.Y. Wibisono, R. Govindaraju, D. Irianto, and I. Sudirman, presents information technology vendors' capabilities in managing offshore outsourcing challenges and success. The authors argue that interaction capabilities consisting of communication and coordination have a positive impact on outsourcing success, and that these capabilities are in turn influenced by management capability.

The last paper, written by H. Iridiastadi, B. Anggawisnu, F.S. Didin, and P.A.R. Yamin, investigates the prevalence of musculoskeletal (MS) complaints among hospital nurses and nursing home caregivers. The authors argue that age, poor working posture, excessive effort while handling patients, and working conditions (including length of employment and shift durations) result in an increased chance of MS problems.

I hope that this edition of IJTech conveys some new insights into the way we conduct our research. I am pleased to accept and respond to any comment or enquiry you may have on the direction and content of IJTech, and I invite you to join us in this venture by sending your work for consideration.

With warmest regards from Jakarta,

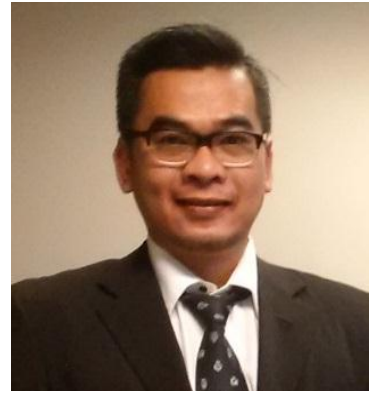

Dr. Mohammed Ali Berawi Editor in Chief 